\title{
The role of temperature as a driver of metabolic flexibility in the Red-billed Leiothrix (Leiothrix lutea)
}

\author{
Danqi Cui ${ }^{1}$, Na Wang ${ }^{1}$, Jingru Ge', Jiaying Xu' ${ }^{1}$, Weihong Zheng ${ }^{1,2}$ and Jinsong Liu ${ }^{1,2^{*}}$
}

\begin{abstract}
Background: The thermoregulatory ability of animals is strongly influenced by the temperature of their environment. Acclimation to cold requires a range of physiological and morphological adjustments. In this study, we tested the hypothesis that a small passerine, the Red-billed Leiothrix (Leiothrix /utea), can maintain homeothermy in cold conditions by adjusting the physiology and biochemistry of its tissue and organs and return to its former physiological and biochemical state when moved to a warm temperature.
\end{abstract}

Methods: Phenotypic variation in thermogenic activity of the Red-billed Leiothrixs (Leiothrix lutea) was investigated under warm $\left(35^{\circ} \mathrm{C}\right)$, normal $\left(25^{\circ} \mathrm{C}\right)$ or cold $\left(15^{\circ} \mathrm{C}\right)$ ambient temperature conditions. Oxygen consumption was measured using an open-circuit respirometry system. Mitochondrial state-4 respiration and cytochrome-c oxidase (COX) activity in liver, kidney heart and pectoral muscle were measured with a Clark electrode.

Results: Birds acclimated to an ambient temperature of $15^{\circ} \mathrm{C}$ for 4 weeks significantly increased their basal metabolic rate (BMR) compared to a control group kept at $25^{\circ} \mathrm{C}$. Birds acclimated to $35^{\circ} \mathrm{C}$ decreased their BMR, gross energy intake (GEI) and digestible energy intake (DEI). Furthermore, birds acclimated to $15^{\circ} \mathrm{C}$ increased state-4 respiration in their pectoral muscles and cytochrome-c oxidase (COX) activity in their liver and pectoral muscle, compared to the $25^{\circ} \mathrm{C}$ control group. Birds acclimated to $35^{\circ} \mathrm{C}$ also displayed lower state-4 respiration and COX activity in the liver, heart and pectoral muscles, compared to those kept at $25^{\circ} \mathrm{C}$. There was a positive correlation between BMR and state-4 respiration, and between BMR and COX activity, in all of the above organs except the liver and heart.

Conclusions: Our study illustrates that the morphological, physiological, and enzymatic changes are associated with temperature acclimation in the Red-billed Leiothrix, and supports the notion that the primary means by which small birds meet the energetic challenges of cold conditions is through metabolic adjustments.

Keywords: Basal metabolic rate, Cold acclimation, Cytochrome C oxidase, Leiothrix lutea, State-4 respiration

\section{Background}

Reversible, temporary, and repeatable phenotypic changes are indicators of phenotypic flexibility (Piersma and Drent 2003; Starck and Rahmaan 2003; McKechnie 2008) and temperate endotherms are ideal study animals for investigating this phenomenon (McKechnie et al. 2006; Liknes and Swanson 2011; Swanson et al. 2014). Morphological, physiological and behavioral adjustments

\footnotetext{
*Correspondence: ljs@wzu.edu.cn

1 School of Life and Environmental Sciences, Wenzhou University, Wenzhou 325035, China

Full list of author information is available at the end of the article
}

to seasonal variations are important adaptive strategies for small birds, many of which use such adjustments to cope with seasonal variation in temperature (Swanson 2010), an important environmental signal for adjusting their seasonal thermoregulation (Swanson 1993, 2001; McKechnie et al. 2007; Zheng et al. 2013a). Many avian species adjust their seasonal physiological changes, especially their energy balance and thermogenesis, in response to temperature changes (Swanson 2001; Wu et al. 2014). In order to cope with a cold environment, many small birds increase their thermogenic capacity in winter conditions (Swanson 1991, 1993; Zheng et al.

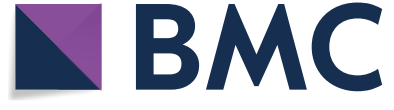

(c) The Author(s) 2019. This article is distributed under the terms of the Creative Commons Attribution 4.0 International License (http://creativecommons.org/licenses/by/4.0/), which permits unrestricted use, distribution, and reproduction in any medium, provided you give appropriate credit to the original author(s) and the source, provide a link to the Creative Commons license, and indicate if changes were made. The Creative Commons Public Domain Dedication waiver (http://creativecommons.org/ publicdomain/zero/1.0/) applies to the data made available in this article, unless otherwise stated. 
2008a). Temperature affects both the mass and basal metabolic rate (BMR) of birds (Williams and Tieleman 2000; Klaassen et al. 2004; Zheng et al. 2014a). BMR is one of the fundamental physiological standards for assessing the energy cost of thermoregulation (McKechnie et al. 2006; McNab 2009; McKechnie and Swanson 2010). Winter- or cold-acclimated birds often exhibit higher BMR than summer- or warm-acclimated ones (Klaassen et al. 2004; Lindsay et al. 2009; Zheng et al. 2013a, 2014a; Zhou et al. 2016). For example, a number of bird species can acclimate to winter or cold conditions by increasing their BMR; these birds include the Hoopoe Larks (Alaemon alaudipes) (Williams and Tieleman 2000), Red Knots (Calidris canutus) (Vézina et al. 2006), Chinese Bulbuls (Pycnonotus sinensis) (Zheng et al. 2008a, 2010, 2013a, 2014a; Hu et al. 2017), Eurasian Tree Sparrows (Passer montanus) (Zheng et al. 2008b, 2014b), Chinese Hwameis (Garrulax canorus) (Zhou et al. 2016) and Silky Starlings (Sturnus sericeus) (Li et al. 2017).

In addition, change in organ mass may also contribute to thermogenesis in birds (Swanson 2010). Increasing BMR during winter and cold acclimation is likely to result from higher support costs for thermogenic tissues (Williams and Tieleman 2000; Swanson et al. 2014). Internal organs such as the liver, kidney, heart and gastrointestinal tract can contribute more than $60 \%$ of the energy expenditure to the basal level, although they represent less than $10 \%$ of body mass (Rolfe and Brown 1997; Clapham 2012). The thermogenic capacity of these internal organs can be enhanced by cold temperature (Hammond et al. 2001; Swanson et al. 2014; Zheng et al. 2014a, 2014b).

Skeletal muscle makes up nearly $40 \%$ of the body mass and exhibits high aerobic capacity, so it is a primary contributor to thermogenesis when the birds are exposed to the cold (Block 1994; Weber and Piersma 1996; Zheng et al. 2008b; Rowland et al. 2015). Furthermore, changes in catabolic enzyme activities and/or capacities for the transport of metabolic substrates could influence the mass-specific metabolic intensities of the organs and thereby affect the metabolic rates at the organismic level (Swanson 1991; Zheng et al. 2008b, 2014a). In addition, state-4 respiration and cytochrome c oxidase (COX), both of which are indicators of oxidative phosphorylation activity, are commonly used as enzymatic markers to indicate altered BMR at the cellular level (Venditti et al. 2004; Swanson et al. 2014; Zheng et al. 2013a, 2014a).

The Red-billed Leiothrix (Leiothrix lutea) is an endemic Asian species that is distributed in southern and eastern China. It is also present in Myanmar, northern Vietnam and in the west to the Himalayas of India (MacKinnon and Phillipps 2000). Within its natural habitat in every type of jungle, leiothrixs preferentially inhabit pine forests with bushes, and at elevations ranging from near sea level to about $2800 \mathrm{~m}$ above it. The leiothrix mainly feeds on arthropods (insects and spiders) and molluscs (snails and slugs) during the breeding season, but eats plants (fruits and seeds) in autumn and winter (MacKinnon and Phillipps 2000). They usually search for food in the lower strata of the vegetation, which is usually obtained from foliage and dead wood. Red-billed Leiothrixs show high body temperature and upper critical temperature, and a relatively narrow thermal neutral zone (Liu et al. 2005). However, there is little available information on the physiological traits of the leiothrix, and exactly how it adjusts to cold temperature is unknown. In order to generate such data, we acclimated leiothrixs to different ambient temperatures $\left(15,25\right.$ and $\left.35^{\circ} \mathrm{C}\right)$, and then measured body mass, BMR, and energy budget of the whole bird, as well as of the liver, kidney, heart, pectoral muscle, and gastrointestinal tract (gizzard, small intestine, and rectum) masses at the organismal level. In addition, we also measured state- 4 respiration and COX activity of the heart, liver, kidneys, and pectoral muscle. We hypothesized that cold temperature might act as a factor that could enhance the thermogenesis of Red-billed Leiothrixs. We predicted that the birds acclimated to cold temperatures would show increased body mass, BMR, energy budget and internal organs, and elevated thermogenic capacities of respiratory enzymes in internal organs and muscle, relative to conspecific individuals acclimated to warm conditions.

\section{Methods \\ Animals}

Our study site was in Wenzhou City, Zhejiang Province $\left(27^{\circ} 29 \mathrm{~N}, 120^{\circ} 51^{\prime} \mathrm{E} ; 14 \mathrm{~m}\right.$ a.s.l.), China. Wenzhou has a warm-temperate climate with an average annual rainfall of $1500 \mathrm{~mm}$. The average daily temperature is $28-39{ }^{\circ} \mathrm{C}$ in July and $3-8{ }^{\circ} \mathrm{C}$ in January (Zheng et al. 2008a, 2014a; Wu et al. 2015).

Thirty male Red-billed Leiothrixs (Leiothrix lutea) were caught in mist nets in October 2013, transported to our laboratory where they were put in separate cages $(60 \mathrm{~cm} \times 60 \mathrm{~cm} \times 30 \mathrm{~cm})$. Birds were kept at $25 \pm 1{ }^{\circ} \mathrm{C}$ under a 12:12-h light-dark photoperiod (lights on at 0600). Birds had unrestricted access to commercial leiothrix pellets (Xietong Bioengineering Co. Ltd, Jiangsu, China) and water. Birds were maintained under these conditions for a fortnight before being assigned to one of three groups: a control $\left(25^{\circ} \mathrm{C}\right)$ group, a low temperature $\left(15{ }^{\circ} \mathrm{C}\right)$ group, and a warm $\left(35^{\circ} \mathrm{C}\right)$ group, with 10 birds per group. Each group was kept at the specified temperature for 4 weeks. All the procedures involving animals were reviewed and approved by the Animal Care and Use Committee of the University of Wenzhou. 


\section{Measurement of metabolic rate}

The metabolic rates of the birds were estimated by measuring their oxygen consumption in an open-circuit respirometry system (model S-3A/I; AEI Technologies, Pittsburgh, PA). Measurements began after birds came to rest in the dark in $1.5 \mathrm{~L}$ plastic metabolic chambers housed inside a temperature-controlled cabinet (Artificial Climatic Engine BIC-300; Boxun, Shanghai, China). This unit could regulate ambient temperature within $\pm 0.5{ }^{\circ} \mathrm{C}$. A perch was provided for the bird to perch on (Smit and McKechnie 2010). Water and $\mathrm{CO}_{2}$ were removed from the air passing in and out of the metabolic chamber with silica gel/soda lime/silica (Zheng et al. 2014a; Zhou et al. 2016). Dry $\mathrm{CO}_{2}$-free air was passed through the chamber at $300 \mathrm{~mL} / \mathrm{min}$ using a flow control system (AEI Technologies R-1), and calibrated with a general purpose thermal mass flowmeter (4100 series; TSI, Shoreview, MN; $\mathrm{McNab}$ 2006) and the fractional $\mathrm{O}_{2}$ concentration in the inlet chamber air was measured with an oxygen sensor (AEI Technologies N-22 M; Zheng et al. 2014a). Oxygen consumption was measured at $30 \pm 0.5{ }^{\circ} \mathrm{C}$, i.e. within the thermal neutral zone of the Red-billed Leiothrix (Liu et al. 2005). After a $1 \mathrm{~h}$ equilibration period the amount of oxygen in excurrent air was recorded every $10 \mathrm{~s}$ for $1 \mathrm{~h}$. An individual's metabolic rate was the mean of its 30 lowest consecutive oxygen consumption recordings (about $5 \mathrm{~min}$ ). Baseline $\mathrm{O}_{2}$ levels were measured before and after each session. Food was removed from the chamber $4 \mathrm{~h}$ prior to each measurement to minimize the heat decrease associated with feeding (Liu et al. 2005). The birds were allowed to perch calmly in the chamber for at least one hour before oxygen consumption was recorded. Metabolic rates are expressed as $\mathrm{mL} \mathrm{O}_{2} / \mathrm{h}$ (Hayes 2001) and were estimated with Eq. (2) of Hill (1972). This was then used to calculate the value under standard temperature, pressure, and dry gas (STPD) conditions (SchmidtNielsen 1997). Body temperature $\left(T_{\mathrm{b}}\right)$ was measured during the metabolic measurement by inserting a lubricated thermocouple (Perfect-Prime company) into each bird's cloaca. Outputs were digitized with an Oakton thermocouple meter (Eutech Instruments, Singapore). The average body mass of each experimental group was measured before and after the experiment. All measurements were conducted daily between 2000 and 2400 .

\section{Energy budget}

Digestible energy intake was regarded as the index of total daily energy expenditure. Leftover food and feces were collected once every 3 days prior to temperature acclimation (week 0), then once every 7 days for the remainder of the experiment. The food residues were separated manually from the feces before being dried to a constant mass in a $60{ }^{\circ} \mathrm{C}$ oven. A C200 oxygen bomb calorimeter (IKA Instrument, Germany) was used to measure the calorie content of residual food and feces. Gross energy intake (GEI), fecal energy (FE), digestible energy intake (DEI), and digestibility were calculated according the methods described in Ni et al. (2011) and Zhou et al. (2016) as follows:

$$
\begin{aligned}
& \text { GEI }(\mathrm{kJ} / \text { day })=\text { Dry food intake (g/day) } \\
& \times \text { caloric value of dry food }(\mathrm{kJ} / \mathrm{g}) \\
& \mathrm{FE}(\mathrm{kJ} / \text { day })=\text { Dry mass of feces }(\mathrm{g} / \text { day }) \\
& \times \text { caloric value of dryfeces }(\mathrm{kJ} / \mathrm{g}) \\
& \operatorname{DEI}(\mathrm{kJ} / \text { day })=\text { GEI }(\mathrm{kJ} / \text { day })-\mathrm{FE}(\mathrm{kJ} / \text { day }) \\
& \text { Digestibility }(\%)=\text { DEI }(\mathrm{kJ} / \text { day }) / \text { GEI }(\mathrm{kJ} / \text { day }) \times 100 \%
\end{aligned}
$$

\section{Measurements of organ masses}

The birds were euthanized at the end of the experiment by cervical dislocation, and the heart, liver, kidney and pectoral muscles were extracted and weighed to the nearest $0.1 \mathrm{mg}$. Samples of the liver, kidney, heart, and pectoral muscle were used for the measurement of state-4 respiration and COX activity (Zheng et al. 2014a). The gizzard, small intestine and rectum were also removed and weighed $( \pm 0.1 \mathrm{mg})$, rinsed with saline to remove all the gut contents, and then dried and reweighed. The remaining part of the liver, kidney, heart, pectoral muscle and gastrointestinal tract (gizzard, small intestine and rectum) were each dried in a $65^{\circ} \mathrm{C}$ oven for two more days to obtain a constant mass, and then weighed to the nearest $0.1 \mathrm{mg}$ (Williams and Tieleman 2000; Liu and Li 2006).

\section{Measurements of tissue state- 4 respiration and cytochrome c oxidase (COX) activity}

State-4 respiration in the liver, kidney, heart, and pectoral muscle was measured at $30{ }^{\circ} \mathrm{C}$ in $1.96 \mathrm{~mL}$ of respiration medium (225 mmol/L sucrose, $50 \mathrm{mmol} / \mathrm{L}$ Tris/ $\mathrm{HCl}, 5 \mathrm{mmol} / \mathrm{L} \mathrm{MgCl}_{2}, 1 \mathrm{mmol} / \mathrm{L}$ EDTA and $5 \mathrm{mmol} / \mathrm{L}$ $\mathrm{KH}_{2} \mathrm{PO}_{4}, \mathrm{pH}$ 7.2) using a Clark electrode (Hansatech Instruments LTD., England, DW-1) essentially as described by Estabrook (1967). State-4 respiration was measured over a $1-\mathrm{h}$ period with succinate as the substrate (Zheng et al. 2008b, 2010, 2013b). COX activity in the liver, kidney, heart, and pectoral muscle was measured polarographically with a Clark electrode at $30{ }^{\circ} \mathrm{C}$ as described in Sundin et al. (1987). State-4 respiration and COX activity were expressed as mass-specific means for 
each organ $\left[\mu \mathrm{mol} \mathrm{O}_{2} /(\right.$ min.organ)] (Wiesinger et al. 1989; Zheng et al. 2013b; Zhou et al. 2016; Li et al. 2017).

\section{Statistics}

All analyses were conducted in SPSS (version 19.0). The normality of variables was assessed using the Kolmogorov-Smirnov test; non-normal variables were $\log _{10}$-transformed. The statistical significance of between-group differences in body mass over time was assessed using a repeated measures analysis of variance (RM-ANOVA). The statistical significance of changes in metabolic rate, GEI, FE and DEI over time was assessed using repeated measures ANCOVA with body mass as a covariate. Because digestibility was expressed as a percentage, an arcsin-square root transformation was applied to these data before they were analyzed. The statistical significance of differences among group means was evaluated with a one-way ANOVA, and that of changes in metabolic rate, GEI, FE, DEI and organ masses was assessed using a one-way ANCOVA with body mass as a covariate. Tukey's HSD post hoc test was used to detect significant differences among groups. We used least-squares linear regression to test the significance of allometric correlations between log body mass, log organ mass and log RMR. For organ mass, we used body mass minus the wet organ mass of the organ in question to avoid statistical problems with part-whole correlations (Christians 1999). If allometric correlations for organ mass were significant, we calculated residuals from the allometric equations and regressed log organ mass residuals against log RMR residuals to determine if the mass of various organs was significantly correlated with RMR. If allometric correlations were not significant, we regressed raw values for log organ mass against log RMR to test for RMR-organ mass correlations (Zheng et al. 2013a, 2014a). Least-squares linear regression was used to evaluate the relationship between $\log B M R$ and $\log$ body mass, and between $\log \mathrm{BMR}, \log$ state- 4 respiration and $\log$ COX. $P$-values $<0.05$ were considered statistically significant.

\section{Results}

\section{Body mass and basal metabolic rate (BMR)}

Overall, birds acclimated at $35{ }^{\circ} \mathrm{C}$ for 4 weeks showed a significant decrease in body mass $\left(F_{2,27}=6.533\right.$, $P=0.005$, one-way ANOVA; Fig. 1a) compared to their counterparts maintained at $25{ }^{\circ} \mathrm{C}$. Significant groupby-time interactions were also detected in body mass $\left(F_{4,54}=9.937, \quad P<0.001\right.$, RM-ANOVA $)$. A significant decrease in body mass was apparent in the warm temperature group after 2 weeks of acclimation at $35{ }^{\circ} \mathrm{C}$ $\left(F_{2,27}=12.493, \quad P<0.001\right.$; Fig. $\left.1 \mathrm{a}\right)$, and this decrease was sustained throughout the 4-week duration of the experiment. No significant differences in $\operatorname{BMR}\left(F_{2,26}=\right.$ $0.010, P=0.990$, one-way ANCOVA) were observed among groups prior to cold or warm acclimation, but birds acclimated at $15{ }^{\circ} \mathrm{C}$ showed a significant increase in BMR, whereas those acclimated at $35{ }^{\circ} \mathrm{C}$ displayed a significant decrease in BMR compared to the $25^{\circ} \mathrm{C}$ control group $\left(F_{2,26}=9.607, P=0.001\right.$; Fig. $\left.1 b\right)$. Significant group-by-time differences in BMR were observed over different times $\left(F_{4,54}=2.572, P=0.048\right.$, RM-ANOVA $)$, but corrected for differences in body mass by repeated measures ANCOVA, BMR did not differ significantly among different groups $\left(F_{4,52}=1.839, P=0.135\right)$. These results indicate that variation in BMR is driven, at least in part, by changes in body mass. Body mass and BMR were positively correlated $\left(R^{2}=0.179, P=0.020\right.$; Fig. $\left.1 \mathrm{c}\right)$. No between-group differences were found in body temperature which averaged about $42.5^{\circ} \mathrm{C}$.

\section{Energy budget}

Birds acclimated at $35{ }^{\circ} \mathrm{C}$ showed significant decreases in GEI $\left(F_{2,26}=10.079, P=0.001\right.$; Fig. $\left.2 \mathrm{a}\right), \mathrm{FE}\left(F_{2,26}=4.414\right.$, $P=0.022$; Fig. $2 b)$, and DEI $\left(F_{2,26}=11.735, P<0.001\right.$; Fig. 2c), but not in digestibility $\left(F_{2,26}=0.808, P=0.457\right.$; Fig. 2d), relative to those acclimated at $25{ }^{\circ} \mathrm{C}$ for four weeks. However, there was no significant difference in GEI, FE and DEI between the $15{ }^{\circ} \mathrm{C}$ and $25^{\circ} \mathrm{C}$ groups. Corrected for differences in body mass by repeated measures ANCOVA, significant group-by-time interactions also occurred in GEI $\left(F_{4,52}=6.835, P<0.001\right)$, FE $\left(F_{4,52}=6.108, \quad P<0.001\right)$, and DEI $\left(F_{4,52}=4.559\right.$, $P=0.003)$, but not in digestibility $\left(F_{4,52}=1.649\right.$, $P=0.176)$. No differences were detected in basal levels (day 0 ) for any of the above indices. However, two weeks of acclimation at $15{ }^{\circ} \mathrm{C}$ significantly increased the value of GEI $\left(F_{2,26}=31.558, P<0.001\right.$; Fig. $\left.2 \mathrm{a}\right)$. The $15^{\circ} \mathrm{C}$ group also had significantly higher $\mathrm{FE}\left(F_{2,26}=18.965, P<0.001\right.$; Fig. $2 b)$ and DEI $\left(F_{2,26}=133.343, P<0.001\right.$; Fig. $\left.2 c\right)$ than the $25{ }^{\circ} \mathrm{C}$ group on week 2 . A positive correlation was found between GEI and body mass (Fig. 3a), between DEI and body mass (Fig. 3b), between GEI and BMR (Fig. 3c), and between DEI and BMR (Fig. 3d).

\section{Organ mass}

ANCOVA (with body mass minus the wet organ mass as the covariate) detected significant differences in the mass of several internal organs among the different groups. The gizzard $\left(F_{2,26}=4.500, P=0.021\right)$, small intestine $\left(F_{2,26}=3.724, P=0.038\right)$, and total gastrointestinal tract $\left(F_{2,26}=6.773, P=0.004\right)$ of the $25^{\circ} \mathrm{C}$ group were significantly heavier than those of the $35{ }^{\circ} \mathrm{C}$ group, but there was no significant difference in the mass of the rectum among the three groups $\left(F_{2,26}=1.983, P=0.158\right)$ (Fig. 4a). A positive correlation was detected between the small 

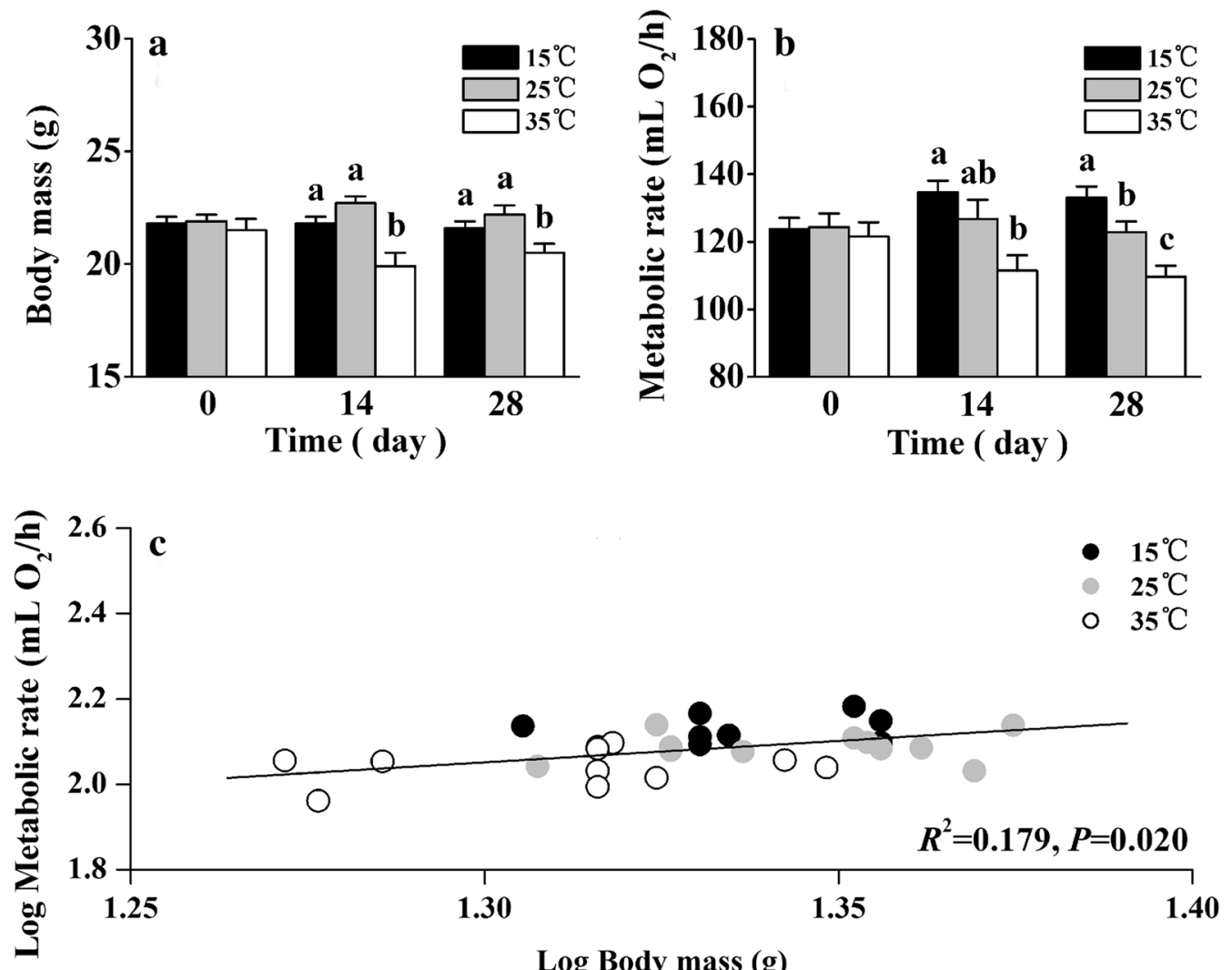

Fig. 1 Comparison of body mass (a), basal metabolic rate (b), and the relationship between body mass and basal metabolic rate (c) among Red-billed Leiothrixs (Leiothrix lutea) acclimated to different temperatures for 4 weeks. Data are shown as mean \pm SEM, and bars with different letters indicate significant differences

intestine and GEI (Fig. 4b), and between the small intestine and DEI (Fig. 4c). The liver $\left(F_{2,26}=13.665, P<0.001\right)$ and kidneys $\left(F_{2,26}=7.906, P=0.002\right)$ of the $25{ }^{\circ} \mathrm{C}$ group were significantly heavier than those of the $35^{\circ} \mathrm{C}$ group, but there was no significant difference in liver and kidney mass between the $15{ }^{\circ} \mathrm{C}$ and $25{ }^{\circ} \mathrm{C}$ groups (Fig. 5a). Allometric relationships between log organ mass and log body mass (minus organ wet mass) were positive for all organs, but only the mass of the liver was significantly correlated with body mass (Table 1). No significant, positive, residual correlations were found between BMR and the dry mass of any other organs (Table 1 ).

\section{Tissue state- 4 respiration and COX activity}

The effects of temperature on organ and muscle function are shown in Fig. 5b, c. State-4 respiration in the liver $\left(F_{2,27}=8.629, P=0.001\right)$, kidney $\left(F_{2,27}=7.529, P=0.003\right)$, heart $\left(F_{2,27}=4.505, P=0.021\right)$ and pectoral muscle of the $15{ }^{\circ} \mathrm{C}$ group was significantly higher than in the $35^{\circ} \mathrm{C}$ group $\left(F_{2,27}=29.586, P<0.001\right)$, but only state-4 respiration in the kidney and pectoral muscle of the $15{ }^{\circ} \mathrm{C}$ group was significantly higher than in the $25^{\circ} \mathrm{C}$ group (Fig. 5b).
The $15{ }^{\circ} \mathrm{C}$ group also had higher COX activity in the kidney $\left(F_{2,27}=5.092, P=0.013\right)$ and heart $\left(F_{2,27}=5.019\right.$, $P=0.014)$ than the $35^{\circ} \mathrm{C}$ group, and significantly higher liver $\left(F_{2,27}=13.454, \quad P<0.001\right)$ and pectoral muscle $\left(F_{2,27}=13.520, P<0.001\right)$ COX activity compared to both the $25^{\circ} \mathrm{C}$ and $35^{\circ} \mathrm{C}$ groups (Fig. $5 \mathrm{c}$ ). BMR and state- 4 respiration, and BMR and COX activity, in the kidney and pectoral muscle were positively correlated (Fig. 6c, d, g, $\mathrm{h})$. In the liver and heart, we observed positive correlations between BMR and state-4 respiration only (Fig. 6a, e).

\section{Discussion}

Ambient temperature is considered to be a key cue for seasonal thermoregulation and a driver of the evolution of a range of adaptations from the biochemical to the morphological level (Swanson 2001; Vézina et al. 2006; McKechnie et al. 2007; Zheng et al. 2013a; Zhou et al. 2016). In this study, we found that an alteration in ambient temperature could significantly influence the thermogenic capacity of Red-billed Leiothrixs. Leiothrixs individuals transferred from ambient temperature $\left(25^{\circ} \mathrm{C}\right)$ 

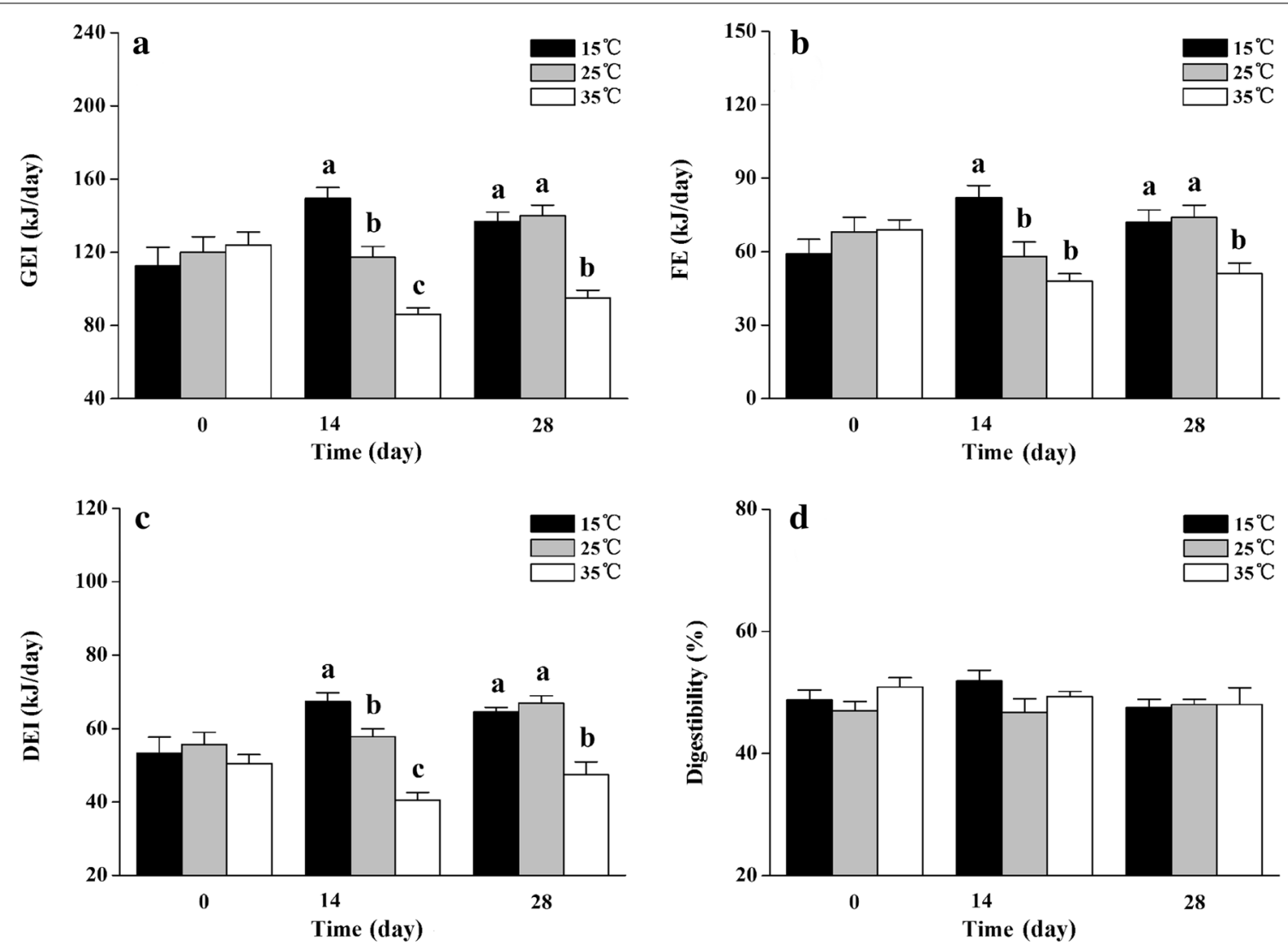

Fig. 2 Comparison of gross energy intake (a), feces energy (b), digestible energy intake (c), and digestibility (d) among Red-billed Leiothrixs (Leiothrix lutea) acclimated to different temperatures for 4 weeks. Data are shown as mean \pm SEM, bars with different letters indicating significant differences. GEI gross energy intake, FE feces energy, DEI digestible energy intake

to $15{ }^{\circ} \mathrm{C}$ displayed increased BMR, energy intake, organ mass, and metabolic enzyme activities, while the magnitudes of these variables all decreased for leiothrix individuals transferred to $35^{\circ} \mathrm{C}$.

BMR is a generally accepted indicator of the metabolic cost of thermoregulation (McKechnie 2008; Swanson 2010; Swanson et al. 2017). The increases in BMR and metabolic activities were consistent with an adaptive response to cold (Swanson 2001; Vézina et al. 2006; McKechnie et al. 2007; Zhou et al. 2016), which involves increased heat production; an increase in heat production requires the expenditure of more energy, an adaptation that is essential to survival. Our data show that cold-acclimated leiothrixs $\left(15{ }^{\circ} \mathrm{C}\right)$ had a higher BMR than control $\left(25{ }^{\circ} \mathrm{C}\right)$ and warm-acclimated leiothrixs $\left(35^{\circ} \mathrm{C}\right)$ (Fig. 1b), indicating higher heat output in the former than in the latter. Similar increases in BMR associated with cold acclimation and seasonal acclimatization have been observed in some avian species (Liknes and Swanson 1996; Williams and Tieleman 2000; Zheng et al. 2008b, 2014b; Zhou et al. 2016). Hoopoe Larks acclimated to $15{ }^{\circ} \mathrm{C}$ had a BMR $43 \%$ higher than those kept at $36{ }^{\circ} \mathrm{C}$ after 3 weeks (Williams and Tieleman 2000). Similarly, the BMR of Red Knots acclimated to $4{ }^{\circ} \mathrm{C}$ was $27 \%$ higher than that of those kept at $25^{\circ} \mathrm{C}$ (Vézina et al. 2006), and the BMR of Laughing Doves (Spilopelia senegalensis) increased when acclimated to cold temperatures but reduced when the same birds were moved to a warm room (McKechnie et al. 2007). As BMR is directly related to the peak metabolic rate of thermogenesis during heightened cold tolerance (Vézina et al. 2006), our data suggest that up-regulation of BMR may be an important component of improved cold tolerance in the leiothrix as it is in many other small birds (Zhou et al. 2016). Adjustments in energy intake and budget can compensate for the increased energy expenditure associated with thermogenesis in cold conditions (Williams and Tieleman 2000). The significant increases in GEI and DEI observed in the low temperature group are consistent with the adaptive changes in energy intake and utilization in response to cold temperature documented in many other small birds (Goymann et al. 2006; Salvante et al. 2010; Syafwan et al. 2012; Wu et al. 2014; Zhou et al. 2016). For example, Williams and Tieleman (2000) observed 


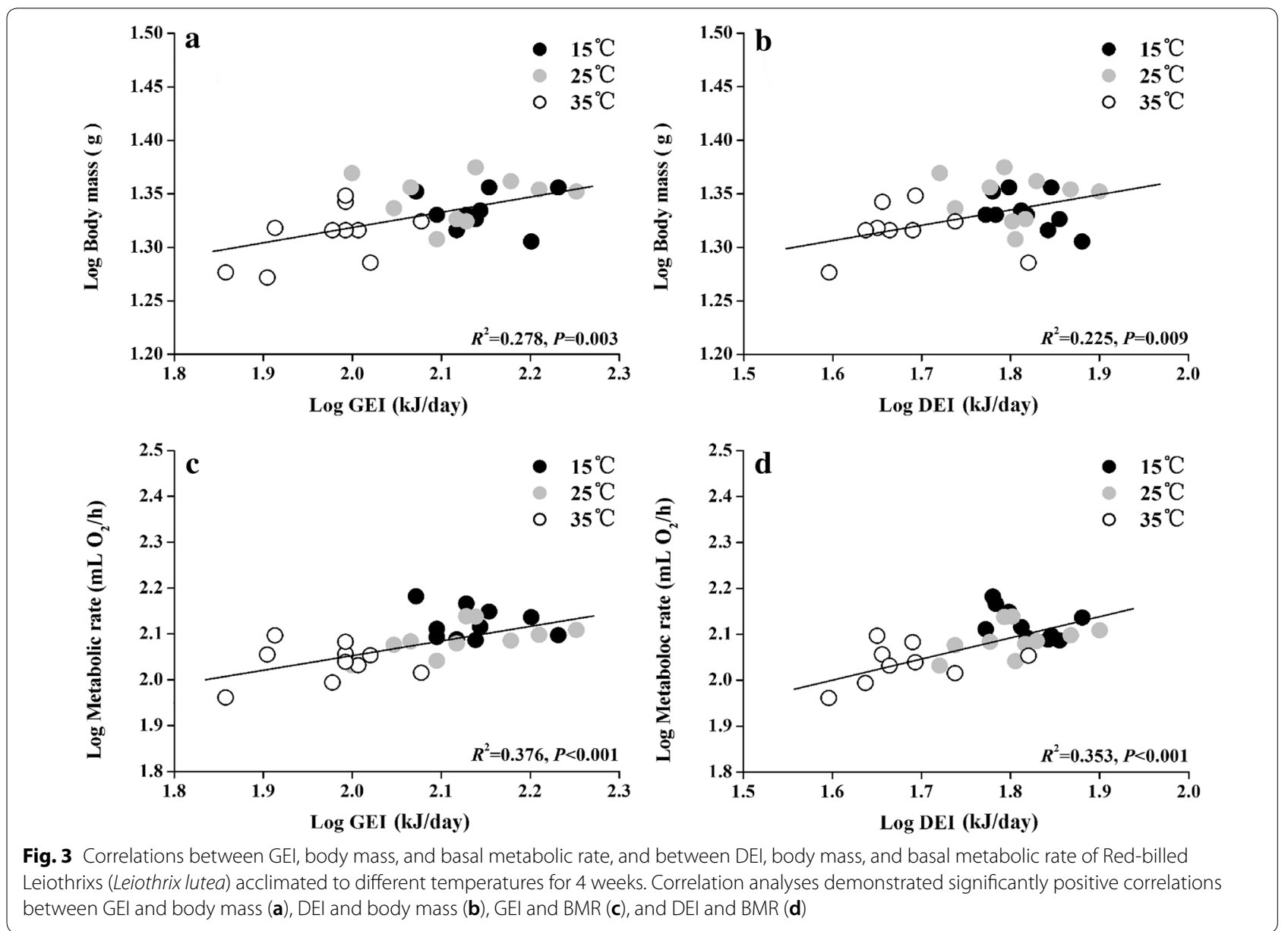

that Hoopoe Larks acclimated at $15{ }^{\circ} \mathrm{C}$ increased their food intake compared to those acclimated at $36^{\circ} \mathrm{C}$. These authors concluded that birds meet the increased cost of thermogenesis in cold temperatures by consuming more food. Vézina et al. (2006) also showed that Red Knots that were kept under either cold, or variable, ambient temperatures required higher food intake than those kept in a thermally neutral zone. Our results showed significant increase in BMR in the $15^{\circ} \mathrm{C}$ group after 4 weeks. Moreover, the GEI and DEI of this group significantly increased over this period. These data provide further evidence of the speed at which morphological, physiological, and behavioral adjustments to cold temperatures can take place (Swanson et al. 2014; Hu et al. 2017). In birds, the small intestine is where the digestion and absorption of food takes place, and it has been shown to vary in a rapid and reversible fashion (Lv et al. 2014). Increased intestinal mass was also seen in leiothrixs kept at $15{ }^{\circ} \mathrm{C}$ compared to their counterparts kept at ambient temperature, with significant correlations between GEI, DEI and small intestine (Fig. 4). Our data suggest that the small intestine mass of cold-acclimated birds increased in response to greater food consumption. These findings are similar to those reported for the Chinese Bulbul (Wu et al. 2015) and the Hwamei (Zhou et al. 2016).

BMR can be regarded as the sum of the metabolic rate of an animal's organs and other metabolically active structures. Increase in BMR in leiothrixs is presumably related to the metabolic and/or morphological adjustments required to meet the extra demand in energy. Leiothrixs responded to the energetic challenge by adjusting their phenotype through the reorganization of internal organ sizes and/or metabolic intensity, and these changes could enable the birds to meet the required energy output (Daan et al. 1990; Liu and Li 2006; Vézina et al. 2006; Swanson 2010; Zheng et al. 2008b, 2014a). Daan et al. (1990) hypothesized that natural selection can adjust the sizes of the internal organs to match the energy requirements of the birds during the provision of parental care, and that size-independent variation in BMR might reflect the relative sizes of the internal organs, which have relatively high rates of oxygen consumption (Piersma and Lindstrom 1997; Williams and Tieleman 2000; Villarin et al. 2003; Zheng et al. 2008b, 2014a). According to 

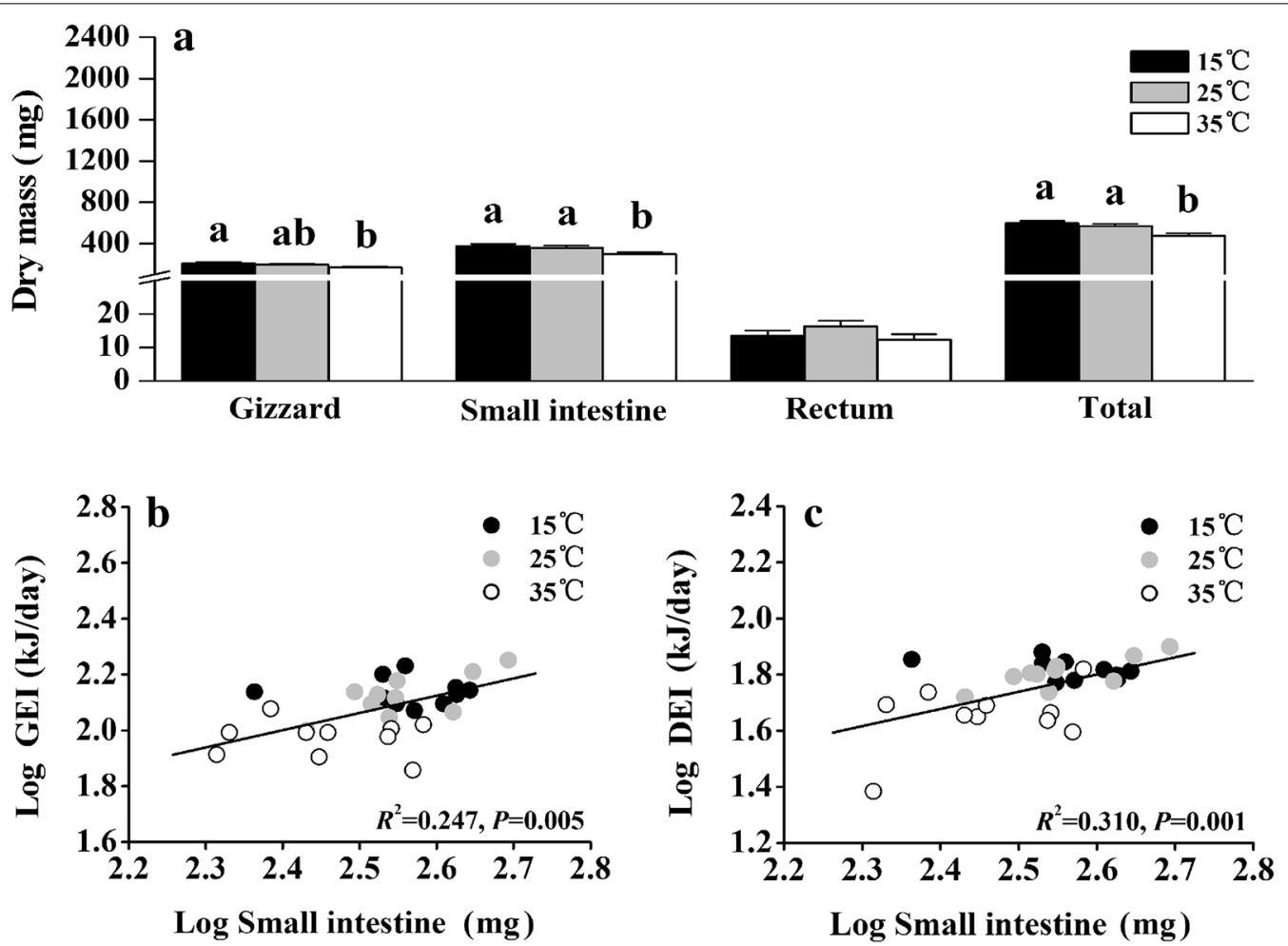

Fig. 4 Comparison of mass in gizzard, small intestine, rectum and gastrointestinal tract (a), the relationship between small intestine and gross energy intake (b), and the relationship between small intestine and digestible energy intake (c) among Red-billed Leiothrixs (Leiothrix lutea) acclimated to different temperatures for 4 weeks. Data are shown as mean \pm SEM, and bars with different letters indicate significant differences. GEI gross energy intake, DEl digestible energy intake

this BMR hypothesis, catabolism in the liver, transport of oxygen from the heart to the tissues, and the elimination of waste by the kidneys have been shown to display high metabolic intensity (Rolfe and Brown 1997). Indeed, although the internal organs (liver, kidney and heart) represent less than $10 \%$ of body mass, they account for $50-70 \%$ of the energy expenditure (Clapham 2012). Being one of the largest and most metabolically active organs, the liver has considerable potential to affect thermogenesis (Villarin et al. 2003; Zheng et al. 2008b, 2014a). The liver's heat generation mechanisms include the uncoupling of oxidative phosphorylation, futile substrate cycling, and its high mass-specific, metabolic rate (Else et al. 2004; Klaassen et al. 2004; Zhou et al. 2016). In volant birds, skeletal muscle typically comprises nearly $40 \%$ of body mass and makes an important contribution to thermogenesis (Weber and Piersma 1996; Swanson et al. 2014; Zheng et al. 2008b, 2014a). More muscle allows more heat production and consequently greater cold resistance (Swanson and Olmstead 1999; Vézina et al. 2007; Swanson et al. 2013, 2014). Leiothrix acclimated to $15^{\circ} \mathrm{C}$ and $25^{\circ} \mathrm{C}$ significantly increased their liver and kidney mass, but not that of their heart or pectoral muscles. There is a link between greater liver and kidney mass and thermogenic capacity. Increased liver and kidney mass may be an adaptive response to the increased food intake and digestion required to sustain a higher metabolic rate (Daan et al. 1990; Williams and Tieleman 2000; Vézina and Williams 2005). However, we cannot exclude the possibility that the heart and pectoral muscles might be involved in cold acclimation in the leiothrixs.

Adjustment of cellular aerobic capacity in tissue and/ or organs may include regulating the activity of key catabolic enzymes, and that of enzymes and transporters involved in substrate delivery pathways (Marsh et al. 1990; Swanson 2010; Liknes and Swanson 2011; Zheng et al. 2014b; Zhou et al. 2016). For example, Hwameis acclimated to cold environment $\left(15{ }^{\circ} \mathrm{C}\right)$ display significantly increased state- 4 respiration and COX in the liver, kidney and pectoral muscle compared to the $36{ }^{\circ} \mathrm{C}$ individuals (Zhou et al. 2016). Cold acclimation of ducklings can also increase the oxidative capacity of the liver and 

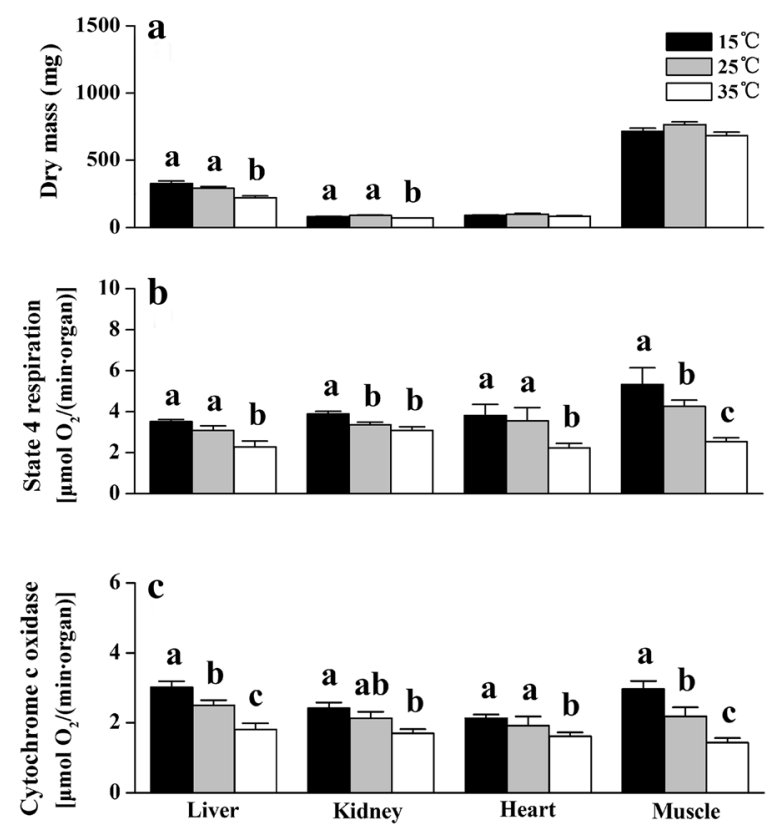

Fig. 5 Differences in mass (a), state-4 respiration (b), and cytochrome c oxidase (c) in the liver, kidneys, heart, and pectoral muscle of Red-billed Leiothrixs (Leiothrix lutea) acclimated to different temperatures for 4 weeks. Data are shown as mean \pm SEM, and bars with different letters indicate significant differences

Table 1 Linear regression statistics for log organ mass versus log body mass (minus wet mass of the organ) allometric equations (allometric correlations) and for log organ mass residuals versus log basal metabolic rate (BMR) residuals (residual correlations)—or log organ mass versus log BMR raw values if allometric equations were not significant-in the Red-billed Leiothrixs (Leiothrix Iutea) after $\mathbf{2 8}$ days of temperature acclimation

\begin{tabular}{|c|c|c|c|c|}
\hline & Liver & Kidney & Heart & Pectoral muscle \\
\hline \multicolumn{5}{|c|}{ Allometric correlations } \\
\hline$R^{2}$ & 0.200 & 0.067 & 0.030 & 0.121 \\
\hline P & 0.013 & 0.167 & 0.361 & 0.059 \\
\hline Slope & 0.219 & 0.164 & 0.100 & 0.364 \\
\hline \multicolumn{5}{|c|}{ Residual correlations } \\
\hline$R^{2}$ & 0.001 & 0.011 & 0.001 & 0.035 \\
\hline$P$ & 0.895 & 0.576 & 0.861 & 0.320 \\
\hline Slope & 0.005 & 0.092 & 0.022 & 0.027 \\
\hline
\end{tabular}

Values in italic type are statistically significant

the pectoral muscles, which can collectively contribute significantly to nonshivering thermogenesis (Barré et al. 1987). Our results show that leiothrixs acclimated to
$15{ }^{\circ} \mathrm{C}$ had higher state- 4 respiration and COX activity in the organs examined than those kept at $25^{\circ} \mathrm{C}$. Moreover, the indicators of cellular aerobic capacity in all the four organs were all significantly and positively correlated with BMR, except for COX activity in the liver and heart (Fig. 5). These data suggested that modulation of tissue and/or organ cellular thermogenesis is a prominent target of temperature acclimation for leiothrixs. This finding is in agreement with previous studies in cold acclimated Dark-eyed Juncos (Junco hyemalis) (Swanson et al. 2014), and seasonally acclimatized Chinese Bulbuls (Zheng et al. 2010, 2014a), Eurasian Tree Sparrows (Liu et al. 2008; Zheng et al. 2008b, 2014b), and in rodents, including Plateau Pikas (Ochotona curzoniae) (Wang et al. 2006a) and Root Voles (Microtus oeconomus) (Wang et al. 2006b). However, other species show no significant temperature or seasonal variation in liver, muscular state-4 respiration, or COX activity (Mujahid and Furuse 2008; Teulier et al. 2010), indicating that cold or winter-induced increases in cellular aerobic capacity are not uniform among small birds. Our results suggest that the leiothrix uses two, organ-specific, adaptive strategies to regulate its body temperature. The first is to increase the total tissue mass and enzymatic activity of liver and kidneys. The second is to increase enzymatic activity in the heart and pectoral muscles. The increased enzymatic activity in these organs may be what allows this species to maintain the higher metabolic rate required for thermogenesis during cold temperatures (Zhou et al. 2016).

\section{Conclusions}

In conclusion, Red-billed Leiothrixs showed (1) enhanced energy budget and BMR, (2) increased internal organ masses (liver, kidney and gastrointestinal tract), and (3) heightened state- 4 respiration and COX activity in the liver, kidney, heart and muscle during cold acclimation. The Red-billed Leiothrix mainly lives in habitats with marked seasonal variation in temperature (the winter temperature in Wenzhou can be at least $20^{\circ} \mathrm{C}$ lower than the summer temperature, Zheng et al. 2008a, 2014a). In winter, small birds typically show enhanced thermogenic capacity that is considered to be an important adaptation for their survival (Zheng et al. 2008a, 2014a). Leiothrixs acclimated to a cold temperature attained higher internal organ mass, thermogenic capacity and energy intake than those acclimated to a warmer temperature. These results support the hypothesis that temperature is important environmental cue for adaptive adjustment of energy metabolism and thermogenesis in birds. The morphological, physiological and biochemical changes induced 

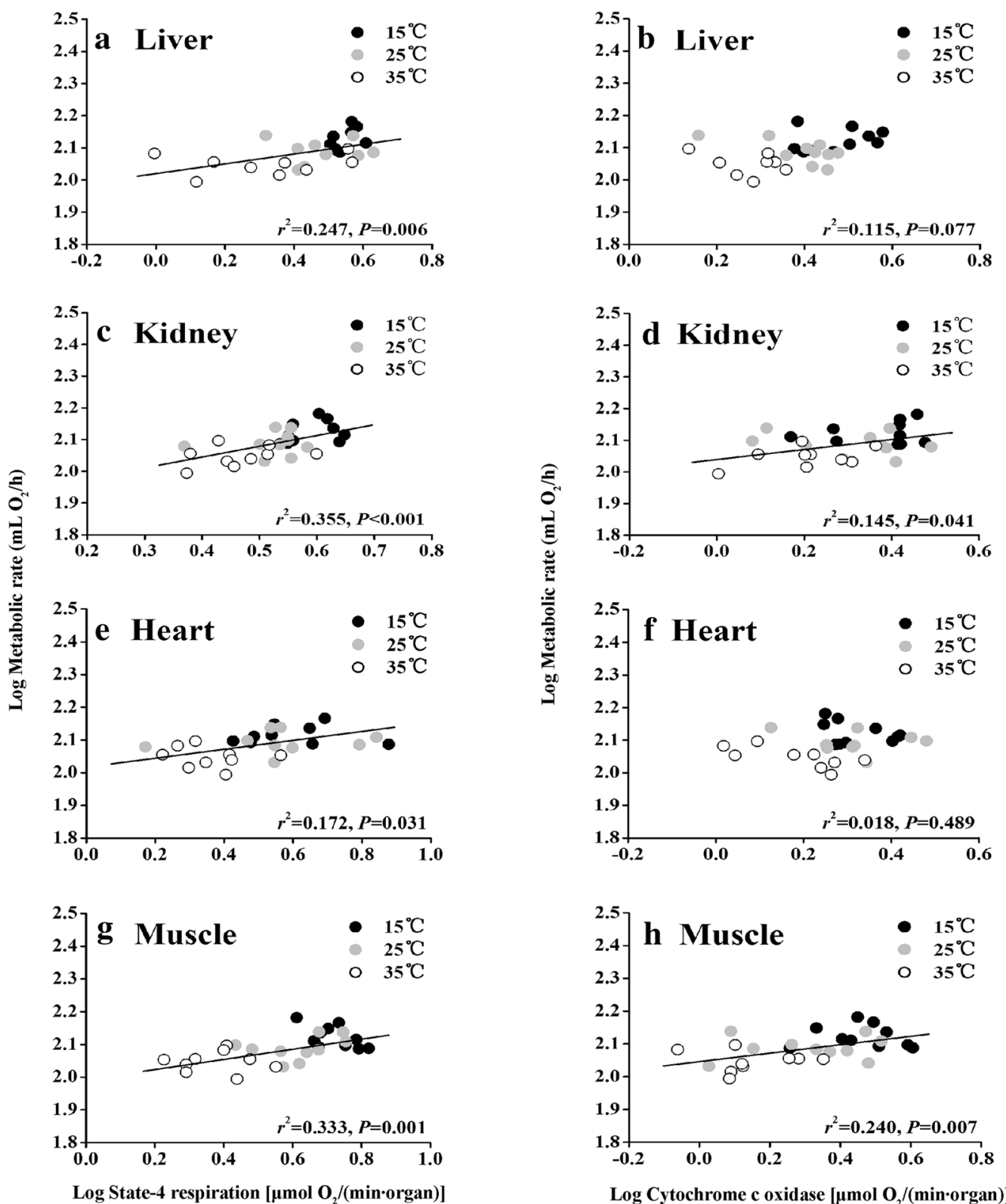

Log Cytochrome c oxidase [ $\left.\mu \mathrm{mol} \mathrm{O}_{2} /(\min \cdot 0 \mathrm{rgan})\right]$

Fig. 6 Correlations between basal metabolic rate (BMR), state-4 respiration, and cytochrome c oxidase in the liver, kidneys, heart, and pectoral muscle of Red-billed Leiothrixs (Leiothrix lutea) acclimated to different temperatures for 4 weeks. Correlation analyses demonstrated that liver state-4 respiration (a), kidney state-4 respiration (c), kidney cytochrome c oxidase (COX) activity (d), heart state-4 respiration (e), muscle state-4 respiration $(\mathbf{g})$, and muscle COX activity (h) were significantly positively correlated with BMR, but liver (b) and kidney (f) COX activities were not significantly correlated with BMR

by cold temperatures may lead to energy expenditure, thereby enhancing the survival of the Red-billed Leiothrix in winter, the most energetically challenging time of the year. Good quality transcriptomic and metabonomic data is required to fully understand the complex mediation of physiological and biochemical processes that occurs during seasonal acclimatization (Teulier et al. 2010; Stager et al. 2015; Zhang et al. 2015). 


\section{Acknowledgements}

We thank Dr. Ron Moorhouse for revising the English. Thanks to all the members of Animal Physiological Ecology Group, and Institute of Applied Ecology of Wenzhou University, for their helpful suggestions.

\section{Authors' contributions}

WZ and JL designed the study. DC, NW, JG and JX performed the work. DC, $J G$ and JX analyzed the data, and DC, JG, WZ and JL wrote the manuscript. All authors participated in revising the manuscript. All authors read and approved the final manuscript.

\section{Funding}

This study was supported by grants from the National Natural Science Foundation of China (Grant Nos. 31470472 and 31971420), the National Undergraduate "Innovation" Project and the "Xinmiao" Project in Zhejiang Province.

\section{Availability of data and materials}

The datasets used in the present study are available from the corresponding author on request.

\section{Ethics approval and consent to participate}

All experimental procedures were approved by the Animal Care and Use Committee of the Wenzhou University.

\section{Consent for publication}

Not applicable.

\section{Competing interests}

The authors declare that they have no competing interests.

\section{Author details}

${ }^{1}$ School of Life and Environmental Sciences, Wenzhou University, Wenzhou 325035, China. ${ }^{2}$ Zhejiang Provincial Key Lab for Subtropical Water Environment and Marine Biological Resources Protection, Wenzhou 325035, China.

Received: 22 March 2019 Accepted: 14 November 2019

Published online: 10 December 2019

\section{References}

Barré H, Bailly L, Rouanet JL. Increased oxidative capacity in skeletal muscles from cold-acclimated ducklings: a comparison with rats. Comp Biochem Phys B. 1987;88:519-22.

Block BA. Thermogenesis in muscle. Annu Rev Physiol. 1994;56:535-77.

Christians JK. Controlling for body mass effects: is part whole correlation important? Physiol Biochem Zool. 1999;72:250-3.

Clapham JC. Central control of thermogenesis. Neuropharmacology. 2012;63:111-23.

Daan S, Masman D, Groenewold A. Avian basal metabolic rates: their association with body composition and energy expenditure in nature. Am J Physiol. 1990;259:R333-40.

Else PL, Brand MD, Turner N, Hulbert AJ. Respiration rate of hepatocytes varies with body mass in birds. J Exp Biol. 2004;207:2305-11.

Estabrook RW. Mitochondrial respiratory control and polarographic measurement of ADP/O ratio. In: Estabrook RW, Pullman ME, editors. Methods in enzymes, X. New York: Academic Press; 1967. p. 41-7.

Goymann W, Trappschuh M, Jensen W, Schwabl I. Low ambient temperature increases food intake and dropping production, leading to incorrect estimates of hormone metabolite concentrations in European stonechats. Horm Behav. 2006;49:644-53.

Hammond KA, Szewczak J, Król E. Effects of altitude and temperature on organ phenotypic plasticity along an altitudinal gradient. J Exp Biol. 2001:204:1991-2000.

Hayes JP. Mass-specific and whole-animal metabolism are mot the same concept. Physiol Biochem Zool. 2001;74:147-50.

Hill RW. Determination of oxygen consumption by use of the paramagnetic oxygen analyzer. J Appl Physiol. 1972;33:261-3.

Hu SN, Zhu YY, Lin L, Zheng WH, Liu JS. Temperature and photoperiod as environmental cues affect body mass and thermoregulation in Chinese bulbuls, Pycnonotus sinensis. J Exp Biol. 2017;220:844-55.
Klaassen M, Oltrogge M, Trost L. Basal metabolic rate, food intake, and body mass in cold- and warm-acclimated garden warblers. Comp Biochem Phys A. 2004;137:639-47.

Li M, Sun YQ, Mao HZ, Xu JH, Zheng WH, Liu JS. Seasonal phenotypic flexibility in body mass, basal thermogenesis, and tissue oxidative capacity in the male Silky Starling (Sturnus sericeus). Avian Res. 2017:8:25.

Liknes ET, Swanson DL. Seasonal variation in cold tolerance, basal metabolic rate, and maximal capacity for thermogenesis in white-breasted nuthatches Sitta carolinensis and downy woodpeckers Picoides pubescens, two unrelated arboreal temperate residents. J Avian Biol. 1996;27:279-88.

Liknes ET, Swanson DL. Phenotypic flexibility in passerine birds: seasonal variation of aerobic enzyme activities in skeletal muscle. J Therm Biol. 2011:36:430-6.

Lindsay CV, Downs CT, Brown M. Physiological variation in Amethyst Sunbirds (Chalcomitra amethystina) over an altitudinal gradient in winter. J Exp Biol. 2009:212:483-93.

Liu JS, Li M. Phenotypic flexibility of metabolic rate and organ masses among tree sparrows Passer montanus in seasonal acclimatization. Acta Zool Sin. 2006;52:469-77.

Liu JS, Wang DH, Sun RY. Climatic adaptations in metabolisms of four species of small birds in China. Acta Zool Sin. 2005;51:24-30.

Liu JS, Li M, Shao SL. Seasonal changes in thermogenic properties of liver and muscle in tree sparrows Passer montanus. Acta Zool Sin. 2008;54:777-84.

Lv JW, Xie ZL, Sun YR, Sun CR, Liu LR, Yu TF, et al. Seasonal plasticity of duodenal morphology and histology in Passer montanus. Zoomorphology. 2014;133:435-43.

MacKinnon J, Phillipps K. A field guide to the birds of China. London: Oxford University Press; 2000.

Marsh RL, Dawson WR, Camilliere JJ, Olson JM. Regulation of glycolysis in the pectoralis muscles of seasonally acclimatized American goldfinches exposed to cold. Am J Physiol. 1990:258:R711-7.

McKechnie AE. Phenotypic flexibility in basal metabolic rate and the changing view of avian physiological diversity: a review. J Comp Physiol B. 2008;178:235-47.

McKechnie AE, Swanson DL. Sources and significance of variation in basal, summit and maximal metabolic rates in birds. Curr Zool. 2010;56:741-58.

McKechnie AE, Freckleton RP, Jetz W. Phenotypic plasticity in the scaling of avian basal metabolic rate. Proc R Soc B. 2006:273:931-7.

McKechnie AE, Chetty K, Lovegrove BG. Phenotypic flexibility in basal metabolic rate in laughing doves: responses to short-term thermal acclimation. J Exp Biol. 2007;210:97-106.

McNab BK. The relationship among flow rate, chamber volume and calculated rate of metabolism in vertebrate respirometry. Comp Biochem Phys A. 2006;145:287-94

McNab BK. Ecological factors affect the level and scaling of avian BMR. Comp Biochem Phys A. 2009;152:22-45.

Mujahid A, Furuse M. Homeothermy in neonatal chicks exposed to low environmental temperature with or without intracerebroventricular administration of corticotropin-releasing factor. FEBS Lett. 2008;582:3052-60.

Ni XY, Lin L, Zhou FF, Wang XH, Liu JS. Effect of photoperiod on body mass, organ masses and energy metabolism in Chinese bulbul (Pycnonotus sinensis). Acta Ecol Sin. 2011;31:1703-13.

Piersma T, Lindstrom Å. Rapid reversible changes in organ size as a component of adaptive behavior. Trends Ecol Evol. 1997;12:134-8.

Piersma T, Drent J. Phenotypic flexibility and the evolution of organismal design. Trends Ecol Evol. 2003;18:228-33.

Rolfe DF, Brown GC. Cellular energy utilization and molecular origin of standard metabolic rate in mammals. Physiol Rev. 1997;77:731-58.

Rowland A, Bal NC, Periasamy M. The role of skeletal-muscle-based thermogenic mechanisms in vertebrate endothermy. Biol Rev. 2015:90:1279-97.

Salvante KG, Vézina F, Williams TD. Evidence for within-individual energy reallocation in cold-challenged, egg-producing birds. J Exp Biol. 2010;213:1991-2000

Schmidt-Nielsen K. Animal physiology: adaptation and environment. London: Cambridge University Press; 1997.

Smit B, McKechnie AE. Avian seasonal metabolic variation in a subtropical desert: basal metabolic rates are lower in winter than in summer. Funct Ecol. 2010;24:330-9.

Stager M, Swanson DL, Heviron ZA. Regulatory mechanisms of metabolic flexibility in the dark-eyed junco (Junco hyemalis). J Exp Biol. 2015;218:767-77. 
Starck JM, Rahmaan GHA. Phenotypic flexibility of structure and function of the digestive system of Japanese quail. J Exp Biol. 2003;206:1887-97.

Swanson DL. Substrate metabolism under cold stress in seasonally acclimatized dark-eyed juncos. Physiol Zool. 1991;64:1578-92.

Swanson DL. Cold tolerance and thermogenic capacity in Dark-eyed Juncos in winter: geographic variation and comparison with American Tree Sparrows. J Therm Biol. 1993;18:275-81.

Swanson DL. Are summit metabolism and thermogenic endurance correlated in winter-acclimatized passerine birds? J Comp Physiol B. 2001;171:475-81.

Swanson DL. Seasonal metabolic variation in birds: functional and mechanistic correlates. In: Thompson CF, editor. Current ornithology. Berlin: Springer; 2010. p. $75-129$.

Swanson DL, Olmstead K. Evidence for a proximate influence of winter temperature on metabolism in passerine birds. Physiol Biochem Zool. 1999;72:566-75.

Swanson DL, Zhang Y, King M. Individual variation in thermogenic capacity is correlated with flight muscle size but not cellular metabolic capacity in American Goldfinches (Spinus tristis). Physiol Biochem Zool. 2013;86:421-31.

Swanson DL, Zhang Y, Liu JS, Merkord CL, King MO. Relative roles of temperature and photoperiod as drivers of metabolic flexibility in dark-eyed juncos. J Exp Biol. 2014;217:866-75.

Swanson D, McKechnie AE, Vézina F. How low can you go? An adaptive energetic framework for interpreting basal metabolic rate variation in endotherms. J Comp Physiol B. 2017;187:1039-56.

Sundin U, Moore G, Nedergaard J, Cannon B. Thermogenin amount and activity in hamster brown fat mitochondria: effect of cold acclimation. Am J Physiol. 1987;252:R822-32.

Syafwan S, Wermink GJD, Kwakkel RP, Verstegen MWA. Dietary self-selection by broilers at normal and high temperature changes feed intake behavior, nutrient intake, and performance. Poult Sci. 2012;91:537-49.

Teulier L, Rouanet J-L, Letexier D, Romestaing C, Belouze M, Rey B, et al. Coldacclimation-induced non-shivering thermogenesis in birds is associated with upregulation of avian UCP but not with innate uncoupling or altered ATP efficiency. J Exp Biol. 2010;213:2476-82.

Venditti P, De Rosa R, Caldarone G, Di Meo S. Functional and biochemical characteristics of mitochondrial fractions from rat liver in cold-induced oxidative stress. Cell Mol Life Sci. 2004;61:3104-16.

Vézina F, Williams TD. Interaction between organ mass and citrate synthase activity as an indicator of tissue maximal oxidative capacity in breeding European starlings: implications for metabolic rate and organ mass relationships. Funct Ecol. 2005;19:119-28.

Vézina F, Jalvingh K, Dekinga A, Piersma T. Acclimation to different thermal conditions in a northerly wintering shorebird is driven by body massrelated changes in organ size. J Exp Biol. 2006;209:3141-54.

Vézina F, Jalvingh KM, Dekinga A, Piersma T. Thermogenic side effects to migratory disposition in shorebirds. Am J Physiol. 2007;292:R1287-97.

Villarin JJ, Schaeffer PJ, Markle RA, Lindstedt SL. Chronic cold exposure increases liver oxidative capacity in the marsupial Monodelphis domestica. Comp Biochem Phys A. 2003;136:621-30.

Wang JM, Zhang YM, Wang DH. Seasonal thermogenesis and body mass regulation in plateau pikas (Ochotona curzoniae). Oecologia. 2006a;149:373-82.
Wang JM, Zhang YM, Wang DH. Seasonal regulations of energetics, serum concentrations of leptin, and uncoupling protein 1 content of brown adipose tissue in root voles (Microtus oeconomus) from the Qinghai-Tibetan plateau. J Comp Physiol B. 2006b;176:663-71.

Weber TP, Piersma T. Basal metabolic rate and the mass of tissues differing in metabolic scope: migration related covariation between individual Knots Calidris canutus. J Avian Biol. 1996;27:215-24.

Wiesinger $\mathrm{H}$, Heldmaier $\mathrm{G}$, Buchberger A. Effect of photoperiod and acclimation temperature on nonshivering thermogenesis and GDP-binding of brown fat mitochondria in the Djungarian hamster Phodopus s. sungorus. Pflug Arch Eur J Phy. 1989;413:667-72.

Williams J, Tieleman BI. Flexibility in basal metabolic rate and evaporative water loss among hoopoe larks exposed to different environmental temperatures. J Exp Biol. 2000;203:3153-9.

Wu MS, Xiao YC, Yang F, Zhou LM, Zheng WH, Liu JS. Seasonal variation in body mass and energy budget in Chinese bulbuls (Pycnonotus sinensis). Avian Res. 2014;5:4.

Wu MX, Zhou LM, Zhao LD, Zhao ZJ, Zheng WH, Liu JS. Seasonal variation in body mass, body temperature and thermogenesis in the Hwamei, Garrulax canorus. Comp Biochem Phys A. 2015;179:113-9.

Zhang Y, Carter T, Eyster K, Swanson DL. Acute cold and exercise training upregulate similar aspects of fatty acid transport and catabolism in house sparrows (Passer domesticus). J Exp Biol. 2015;218:3885-93.

Zheng WH, Liu JS, Jang XH, Fang YY, Zhang GK. Seasonal variation on metabolism and thermoregulation in Chinese bulbul. J Therm Biol. 2008a;33:315-9.

Zheng WH, Li M, Liu JS, Shao SL. Seasonal acclimatization of metabolism in Eurasian tree sparrows (Passer montanus). Comp Biochem Phys A. 2008b;151:519-25.

Zheng WH, Fang YY, Jang XH, Zhang GK, Liu JS. Comparison of thermogenic character of liver and muscle in Chinese bulbul Pycnonotus sinensis between summer and winter. Zool Res. 2010;31:319-27.

Zheng WH, Lin L, Liu JS, Pan H, Cao MT, Hu YL. Physiological and biochemical thermoregulatory responses of Chinese bulbuls Pycnonotus sinensis to warm temperature: phenotypic flexibility in a small passerine. J Therm Biol. 2013a;38:483-90

Zheng WH, Lin L, Liu JS, Xu XJ, Li M. Geographic variation in basal thermogenesis in little buntings: relationship to cellular thermogenesis and thyroid hormone concentrations. Comp Biochem Phys A. 2013b;164:240-6.

Zheng WH, Liu JS, Swanson DL. Seasonal phenotypic flexibility of body mass, organ masses, and tissue oxidative capacity and their relationship to RMR in Chinese bulbuls. Physiol Biochem Zool. 2014a;87:432-44.

Zheng WH, Li M, Liu JS, Shao SL, Xu XJ. Seasonal variation of metabolic thermogenesis in Eurasian tree sparrows Passer montanus over a latitudinal gradient. Physiol Biochem Zool. 2014b;87:704-18.

Zhou LM, Xia SS, Chen Q, Wang RM, Zheng WH, Liu JS. Phenotypic flexibility of thermogenesis in the Hwamei (Garrulax canorus): responses to cold acclimation. Am J Physiol. 2016;310:R330-6.

Ready to submit your research? Choose BMC and benefit from:

- fast, convenient online submission

- thorough peer review by experienced researchers in your field

- rapid publication on acceptance

- support for research data, including large and complex data types

- gold Open Access which fosters wider collaboration and increased citations

- maximum visibility for your research: over $100 \mathrm{M}$ website views per year

At BMC, research is always in progress.

Learn more biomedcentral.com/submissions 